\title{
The impact of aerosol optical depth assimilation on aerosol forecasts and radiative effects during a wild fire event over the United States
}

\author{
D. Chen ${ }^{1}$, Z. Liu ${ }^{1}$, C. S. Schwartz ${ }^{1}$, H.-C. Lin ${ }^{1}$, J. D. Cetola ${ }^{2}$, Y. Gu ${ }^{3}$, and L. Xue ${ }^{1}$ \\ ${ }^{1}$ National Center for Atmospheric Research, Boulder, Colorado, USA \\ ${ }^{2}$ Air Force Weather Agency, Omaha, Nebraska, USA \\ ${ }^{3}$ University of California, Los Angeles, Los Angeles, California, USA \\ Correspondence to: Z. Liu (liuz@ucar.edu)
}

Received: 10 April 2014 - Published in Geosci. Model Dev. Discuss.: 11 June 2014

Revised: 1 October 2014 - Accepted: 17 October 2014 - Published: 19 November 2014

\begin{abstract}
The Gridpoint Statistical Interpolation threedimensional variational data assimilation (DA) system coupled with the Weather Research and Forecasting/Chemistry (WRF/Chem) model was utilized to improve aerosol forecasts and study aerosol direct and semi-direct radiative feedbacks during a US wild fire event. Assimilation of MODIS total $550 \mathrm{~nm}$ aerosol optical depth (AOD) retrievals clearly improved WRF/Chem forecasts of surface $\mathrm{PM}_{2.5}$ and organic carbon (OC) compared to the corresponding forecasts without aerosol data assimilation. The scattering aerosols in the fire downwind region typically cooled layers both above and below the aerosol layer and suppressed convection and clouds, which led to an average of $2 \%$ precipitation decrease during the fire week. This study demonstrated that, even with no input of fire emissions, AOD DA improved the aerosol forecasts and allowed a more realistic model simulation of aerosol radiative effects.
\end{abstract}

\section{Introduction}

Aerosols are known to affect weather and climate by modulating radiation in the atmosphere by either scattering or absorption of sunlight (direct effect, e.g., Rosenfeld et al., 2008); thermodynamic effect on clouds (semi-direct, e.g., Hansen et al., 1997); and altering cloud microphysical processes (indirect effects, e.g., Kaufman and Koren, 2006). Aerosols can scatter incoming solar radiation and cool both the surface and atmosphere (Charlson et al., 1992; Kiehl and Briegleb, 1993). Conversely, absorbing aerosols, such as black carbon (BC) and dust can absorb solar radiation, which heats the local atmosphere (Hansen et al., 1997).

One of the most important short-term effects of aerosols is the impact on local meteorological conditions, especially clouds and precipitation. These changes can be particularly pronounced during biomass burning events when a large amount of aerosols are injected into the atmosphere (e.g., Koren et al., 2004; Wilcox, 2012). Several observational studies have shown evidence of aerosol-induced intensification and weakening of convection with a critical aerosol optical depth (AOD) value $(\sim 0.2-0.4)$, below which additional aerosol enhances convection and precipitation but above which additional aerosol weakens convection and precipitation (Koren et al., 2008; Rosenfeld et al., 2008). For example, Koren et al. (2004) analyzed Moderate Resolution Imaging Spectroradiometer (MODIS) satellite data over the Amazon region during the biomass burning season and found that smoke reduced cumulus cloud cover from $38 \%$ in clean conditions (AOD of $\sim 0.1$ ) to $0 \%$ in heavy smoke (AOD of $\sim 1.3$ ). Andreae et al. (2004) used in situ measurements of cloud condensation nuclei and cloud droplets over the Amazon and found that the suppression of low-level rainout by biomass burning smoke tended to invigorate deep convective clouds, thus increasing precipitation. In addition, aerosolinduced changes in the atmosphere may exert different effects on clouds depending on the type of aerosols (absorbing or scattering) and the vertical distributions of aerosols and clouds (e.g., Rosenfeld et al., 2008).

To accurately simulate aerosol effects, it is necessary to precisely simulate aerosol types and distributions. AOD data assimilation (DA), combining satellite derived AOD 
observations with numerical model output, has proved to be skillful at improving aerosol and AOD forecasts (e.g., Collins et al., 2001; Liu et al., 2011). Liu et al. (2011, hereafter L11) implemented AOD DA within the National Centers for Environmental Prediction (NCEP) Gridpoint Statistical Interpolation (GSI) three-dimensional variational (3DVAR) DA system coupled to the Goddard Chemistry Aerosol Radiation and Transport (GOCART) (Chin et al., 2000, 2002) aerosol scheme within the Weather Research and Forecasting/Chemistry (WRF/Chem) model (Grell et al., 2005). Verification results demonstrated improved aerosol forecasts from AOD DA over a week-long period while studying a dust storm in East Asia. This aerosol DA system was also used to assimilate surface $\mathrm{PM}_{2.5}$ over the US (Schwartz et al., 2012, hereafter S12) and $\mathrm{PM}_{10}$ over China (Jiang et al., 2013).

These previous air-quality-oriented studies (L11; S12; Jiang et al., 2013) illustrated the ability of aerosol DA to improve forecasts of total aerosol mass in terms of AOD, $\mathrm{PM}_{2.5}$ and $\mathrm{PM}_{10}$, but did not verify aerosol speciation forecasts. As pointed out in L11, the aerosol data assimilation system used here directly analyzes 3-D mass concentration of individual aerosol species and allows them to adjust independently with additional constraint from the background error covariance for individual species. A similar method was also adopted by Kahnert (2009) for aerosol inverse modeling. This work builds upon L11 and S12 and serves two purposes. First, this study aims to verify the GSI 3DVAR DA system's capability to analyze and forecast aerosol species, including black carbon (BC) and organic carbon (OC), during a fire event without fire emission input in the WRF/Chem model. Second, the biomass burning aerosol radiative effects (direct and semi-direct) on clouds and precipitation in the downwind region during the fire event are investigated.

\section{Model description and experimental design}

Version 3.4.1 of WRF/Chem was used and configurations mostly followed S12. The model domain (operationally used at the US Air Force Weather Agency) with $20 \mathrm{~km}$ horizontal grid spacing covered a large portion $\left(20^{\circ}\right.$ north) of the Northern Hemisphere with the polar projection (not shown), although our analysis will focus on North American regions where a wild fire occurred (Fig. 1). There were 57 vertical levels extending from the surface to $10 \mathrm{hPa}$. Aerosol direct and semi-direct effects were implemented (Fast et al., 2006) in WRF/Chem by linking the optical properties of simulated GOCART aerosols (OC, BC, sulfate, dust and sea salt) to the Goddard Space Flight Center shortwave radiation scheme (Chou and Suarez, 1994). Aerosol optical properties, including scattering/absorption coefficients and singlescattering albedos, are calculated by the "aerosol chemical to aerosol optical properties" module built in WRF/Chem (Fast et al., 2006; Barnard et al., 2010). Aerosol indirect effects were not implemented for GOCART with the

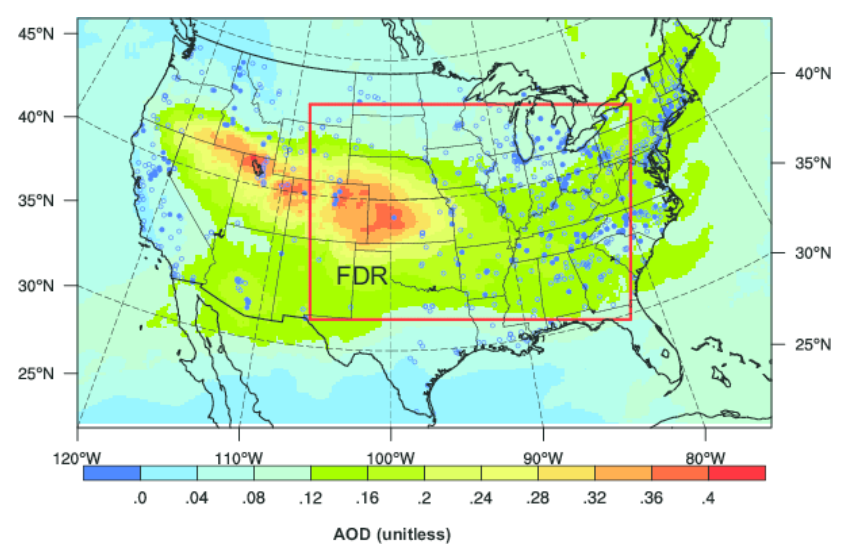

Figure 1. The domain for aerosol verification. The mean AOD difference between the two experiments (MET_AOD minus MET, see text in Sect. 2) for 14-17 August 2012. The locations of AIRNow (open circle) and IMPROVE (dot) sites are also shown. The red rectangle is defined as the fire downwind region (FDR) used in the radiative effect analysis.

WRF/Chem version used. The WRF single-moment sixclass microphysics scheme and the Grell-Devenyi ensemble cumulus scheme (Grell and Devenyi, 2002) were used. Anthropogenic emissions were provided by the $0.5 \times 0.5$ degree Reanalysis of the TROpospheric (RETRO) chemical composition over the past 40 years (http://gcmd. gsfc.nasa.gov/records/GCMD_GEIA_RETRO.html) and the $0.1 \times 0.1$ degree Emission Database for Global Atmospheric Research (EDGAR) (http://themasites.pbl.nl/tridion/ en/themasites/edgar/). Over the US, the high-resolution $(4 \mathrm{~km})$ National Emission Inventory 2005 (NEI'05) emission was used for more accuracy (Kim et al., 2011). Within WRF/Chem, emissions of dust and sea salt were parameterized using the GOCART dust and sea-salt modules (Chin et al., 2002). The lateral boundary conditions (LBCs) for meteorological fields were provided by the NCEP Global Forecast System (GFS). LBCs for chemistry/aerosol fields were idealized profiles embedded within the WRF/Chem model as in S12.

To evaluate the GSI-WRF/Chem system's capability of improving aerosol species and simulating aerosol radiative effects during the fire event, which originated in the western US and sent smoke eastward during 13-18 August 2012 (http://earthobservatory.nasa.gov/IOTD/ view.php?id=78881\&src=ve), two DA experiments were conducted. One experiment assimilated only NCEP conventional meteorological observations (MET) while the other assimilated both meteorological data and MODIS level-2 $(10 \mathrm{~km} \times 10 \mathrm{~km}$ resolution) $550 \mathrm{~nm}$ AOD retrievals obtained from ftp://ladsweb.nascom.nasa.gov/allData/51/MOD06_L2 (and MYD06_L2) (MET_AOD). Only the AOD data flagged as the best quality were used in this study. Each experiment started WRF/Chem simulation with a $6 \mathrm{~h}$ cycling interval 
(a) Western US $\left(\mu \mathrm{g} / \mathrm{m}^{3}\right)$
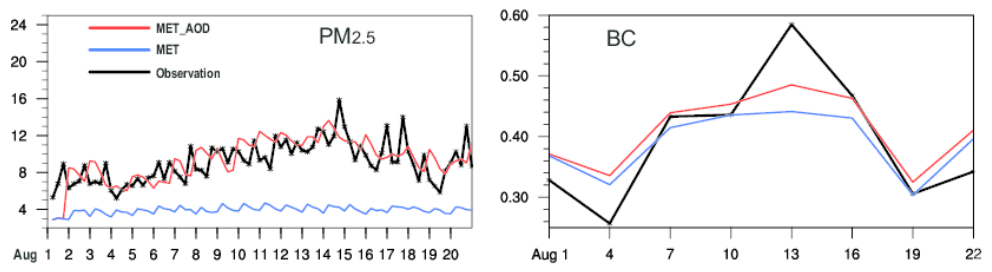

(b) Eastern US $\left(\mu \mathrm{g} / \mathrm{m}^{3}\right)$
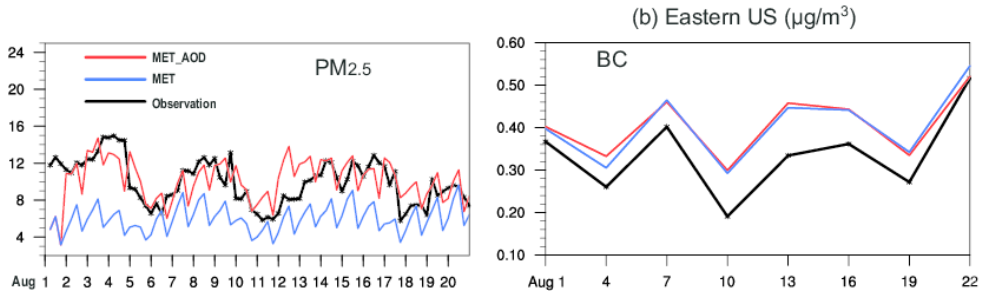
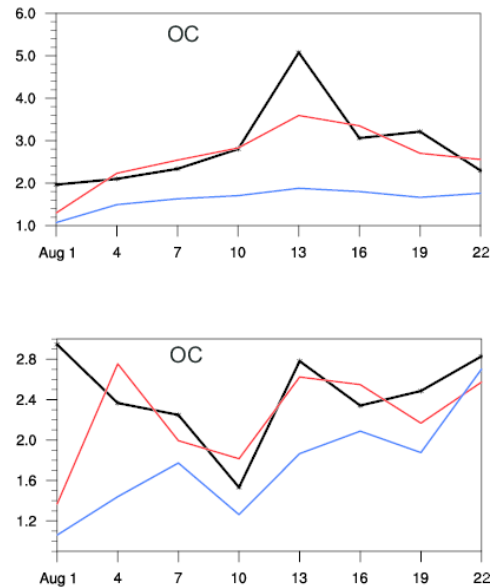

Figure 2. The time series of model predicted ( $6 \mathrm{~h}$ forecasts) and observed $\mathrm{PM}_{2.5}, \mathrm{BC}$ and $\mathrm{OC}$, averaged over the (a) western (130-105 $\left.{ }^{\circ} \mathrm{W}\right)$ and (b) eastern US $\left(105-70^{\circ} \mathrm{W}\right)$ during August 2012. $\mathrm{PM}_{2.5}$ is in $6 \mathrm{~h}$ intervals. $\mathrm{BC}$ and $\mathrm{OC}$ are in $72 \mathrm{~h}$ intervals.

from 00:00 UTC 1 August in order to spin up aerosol fields before the fire event. For MET, GSI 3DVAR meteorological (surface pressure, 3-D wind, temperature and moisture) analyses (Wu et al., 2002) were performed using the previous cycle's $6 \mathrm{~h}$ forecast (meteorological fields only) as the background, and aerosol fields were simply carried over from cycle to cycle (similar to a continuous aerosol forecast). For MET_AOD, GSI 3DVAR updated both meteorological and GOCART aerosol variables (only at 18:00 UTC when AOD data were available over US) every $6 \mathrm{~h}$, again using the previous cycle's $6 \mathrm{~h}$ forecast as the background. The assimilation time window was $\pm 1.5 \mathrm{~h}$ centered at analysis times $(00: 00$, 06:00, 12:00, and 18:00 UTC). This cyclic experimental design was also adopted by L11 and $\mathrm{S} 12$, who assimilated aerosol observations only. No cross-correlation between meteorological and aerosol fields was allowed in MET_AOD even though meteorological and AOD data were assimilated simultaneously. More details related to AOD DA can be found in L11 and S12.

This design permitted a clear isolation of the impact of AOD DA. To investigate aerosol radiative effects, $48 \mathrm{~h}$ forecasts were initialized at 00:00 UTC for each experiment during the fire week. Hourly model outputs were analyzed. Since the meteorological fields after 3DVAR DA in the two experiments were very close, the forecast differences of meteorological fields suggest primarily radiative effects due to fire emitted aerosols.

\section{PM speciation verification}

Surface observations, including hourly $\mathrm{PM}_{2.5}$ from the EPA AIRNow network and $24 \mathrm{~h}$ averaged BC and OC (available every three days) from the Interagency Monitoring of PROtected Visual Environments (IMPROVE) network, were used for aerosol verification. Figure 1 shows the locations of these sites. The averaged AOD differences between the two experiments (MET_AOD minus MET) for the fire period (14-17 August) are also shown in Fig. 1. Significant increases in AOD $(\sim 0.4)$ over the western US and the fire downwind region (FDR, indicated by the red rectangle in Fig. 1) were produced after assimilating MODIS AOD.

Figure 2 shows the average $\mathrm{PM}_{2.5}, \mathrm{BC}$ and $\mathrm{OC}$ observations and model forecasts between 1 and 22 August 2012 over the sites located in the fire originating area (western US $130-105^{\circ} \mathrm{W}$ ) and fire downwind regions (eastern US $\left.105-70^{\circ} \mathrm{W}\right)$. Model outputs from the two experiments were interpolated to the observation sites. The $6 \mathrm{~h}$ WRF/Chem forecasts of $\mathrm{PM}_{2.5}$ were compared with AIRNow observations at 00:00, 06:00, 12:00, 18:00 UTC. To compare the forecasts with IMPROVE $24 \mathrm{~h}$ averaged (from 06:00 to 06:00 UTC) BC and OC observations, the corresponding $6 \mathrm{~h}$ model forecasts were also averaged. Observations (black lines) show large peaks in total $\mathrm{PM}_{2.5}, \mathrm{BC}$ and $\mathrm{OC}$ during the fire event (13-16 August) in the western US, due to strong fire emissions. While the experiment without AOD DA (blue lines) failed to reproduce those peaks and underpredicted aerosol concentrations, most likely a result of the lack of fire emission input in the model, the experiment with AOD DA (red lines) substantially improved surface $\mathrm{PM}_{2.5}$ forecasts. Furthermore, the peaks of individual aerosol species' concentrations (especially OC) were well captured with AOD $\mathrm{DA}$, although $\mathrm{OC}$ and $\mathrm{BC}$ were still underpredicted when the maximum concentrations were reached on 13 August in the western US.

Observations also show increased total $\mathrm{PM}_{2.5}$ and $\mathrm{OC}$ in the downwind region when the smoke was transported eastward during the fire event. MET_AOD improved substantially the simulation with increased $\mathrm{OC}$ and $\mathrm{PM}_{2.5}$ when compared with MET. While MET exhibits a relatively small 
bias for $\mathrm{BC}$, large low biases can be seen for $\mathrm{PM}_{2.5}$ and $\mathrm{OC}$ in both regions even during periods without fire, which may indicate model deficiencies related to emissions and other physical/chemical processes. AOD DA helped correct these biases and improved the simulation for the total mass (i.e., $\mathrm{PM}_{2.5}$ ) and for $\mathrm{OC}$ (and to a lesser extent for $\mathrm{BC}$ in the western US) in this case.

\section{Aerosol radiative feedback}

Fire-emitted aerosols scatter and absorb solar radiation in daytime and thus can affect the atmospheric temperature profiles. Averaged over the FDR region, which was cloudier than the western US during the fire period and thus cloud/precipitation features were more likely to be modified through aerosol semi-direct effects, the time series of hourly model outputs of day- 2 forecasts (i.e., $24-47 \mathrm{~h}$ forecasts valid from 00:00 to 23:00 UTC) of 550 nm AOD and shortwave downward fluxes reaching the surface (SWDOWN) from the two experiments are shown in Fig. 3a-b. The jumps in AOD values from 23:00 to 00:00 UTC are most likely the result of forecast range differences (i.e., 47 vs. $24 \mathrm{~h}$ forecast). The average AOD differences reach as high as $0.16-0.20$ on 17 August, which is almost $80 \%$ of the total AOD from the MET_AOD experiment. The average AOD differences were around 0.08 after 20 August when fire emissions decreased. The AOD increase led to more aerosol scattering and absorption in MET_AOD, which resulted in a SWDOWN reduction of $\sim 10 \mathrm{w} \mathrm{m}^{-2}$ during 15-18 August with much smaller changes afterward. Also note that small SWDOWN differences occurred in the late afternoon of 15 August, which was likely caused by cloud feedback.

Similar to Fig. 3, Fig. 4 shows the FDR-averaged differences of $550 \mathrm{~nm}$ AOD, temperature, relative humidity, vertical velocity, cloud liquid and cloud ice water as a function of height and time (hourly output of day-2 forecasts) between the two experiments. The largest AOD (also OC and BC, not shown) increase due to AOD DA occurred at around 4-5km altitude, indicating upward transport of fire emitted aerosols. This peak AOD height in the AOD DA experiment is consistent with the altitude at which $\mathrm{OC}$ and $\mathrm{BC}$ had maximum background error variances (not shown). The decreased temperature below this level indicates that the additional aerosols cooled the surface layer and planetary boundary layer (PBL, $\sim 2 \mathrm{~km}$ in the afternoon). A weak cooling appeared above the aerosol layer and a weak warming was noted around $15 \mathrm{~km}$. Temperature changed little in the aerosol layer, as the absorbing aerosols (BC and dust) were not dominant in the FDR and no obvious differences of those species were evident between the two experiments (not shown). The relative humidity differences roughly followed the temperature differences, with increased RH in the PBL and above the aerosol layer. Cooler and moister air in the PBL (below $\sim 2 \mathrm{~km}$ ) facilitates low cloud formation from MET_AOD simulations
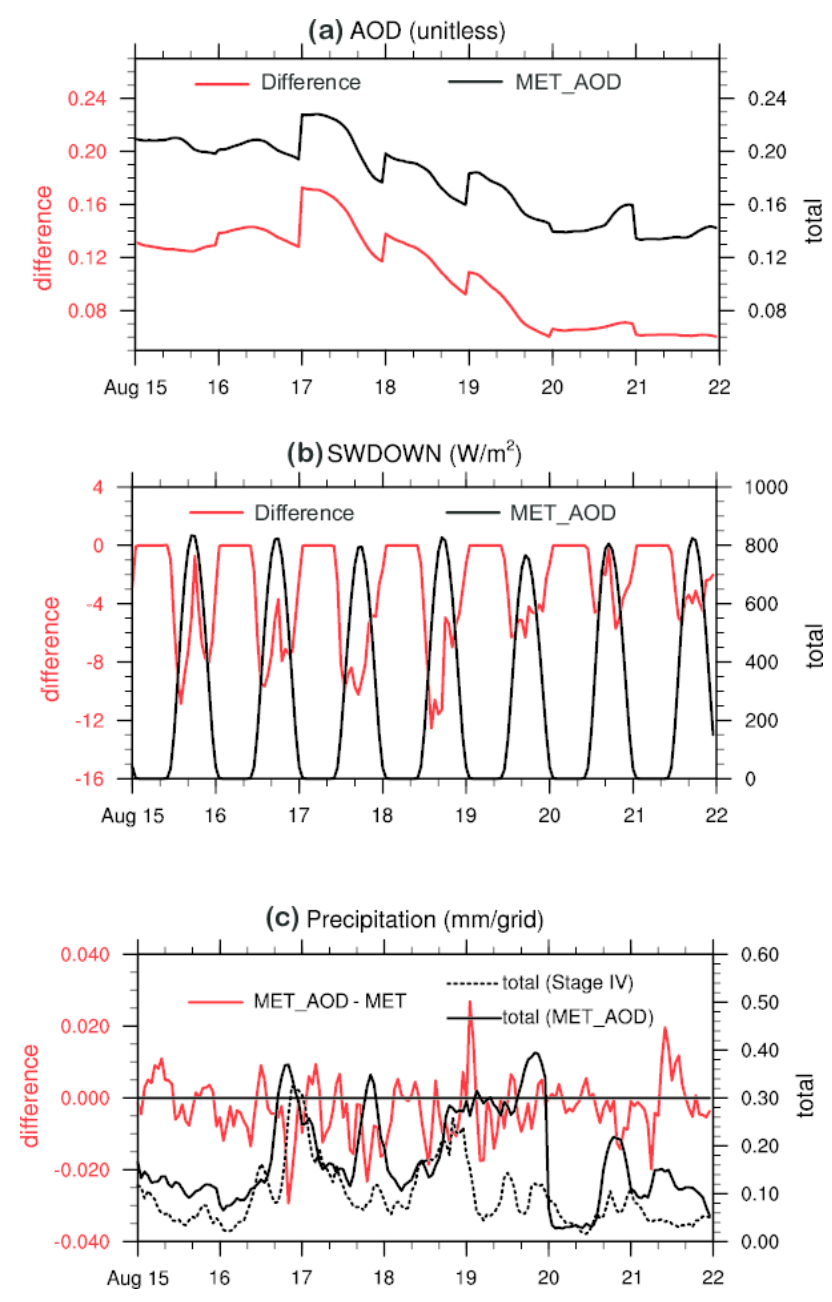

Figure 3. The hourly model output of day-2 forecasts averaged over the FDR for (a) $550 \mathrm{~nm}$ AOD, (b) shortwave downward fluxes and (c) precipitation during 15-21 August. Red lines: the difference of MET_AOD minus MET (left $y$ axis); black lines: the total amount from MET_AOD (right $y$ axis).

(17-19 August), which was especially pronounced on $17 \mathrm{Au}-$ gust when the AOD increase reached its maximum. Middlelevel liquid clouds above the PBL and below the aerosol layer decreased, likely associated with deceased relative humidity. The ice clouds near the tropopause also decreased, which may be related to the suppression of upward motion in the middle and upper troposphere (Fig. 4b). The aerosol direct and semi-direct effects are consistent with Jacobson (2002), and the findings of middle and high cloud suppression are similar to Amazon fire events (Koren et al., 2004; Wu et al., 2011).

Figure $3 \mathrm{c}$ shows the average precipitation differences (red line, left $y$ axis) between the two experiments in the FDR and the corresponding total amount of precipitation $\left(\mathrm{mm} \mathrm{grid}^{-1}\right)$ from model forecasts and Stage IV observations (black lines, right $y$ axis). Surface precipitation was suppressed: 
(a) AOD (unitless)

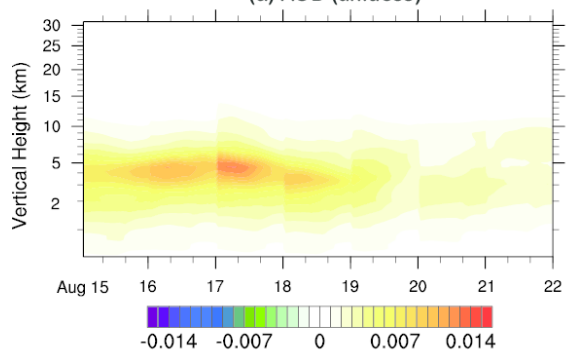

(c) Temperature (K) and Relative Humidity (\%)

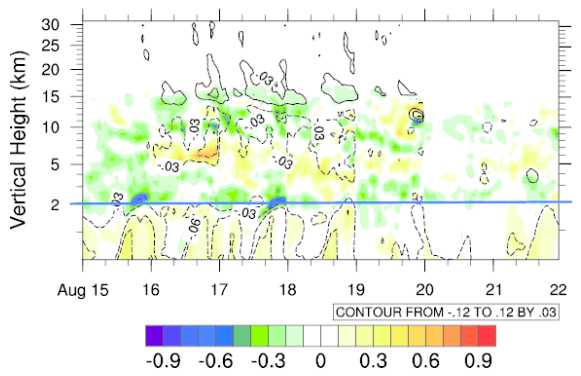

(b) Vertical Velocity $(\mathrm{mm} / \mathrm{s})$

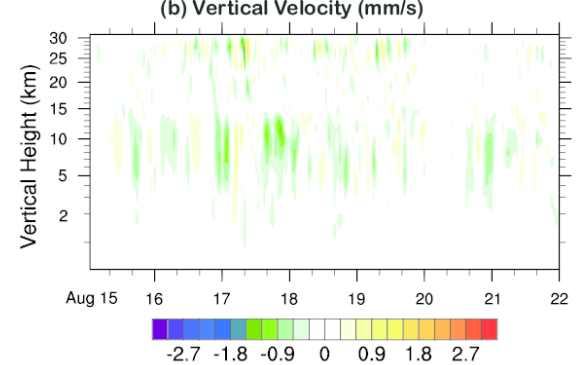

(d) QCLOUD and QICE $(\mathrm{mg} / \mathrm{kg})$

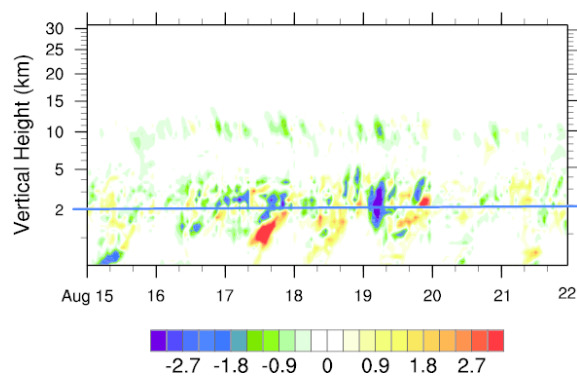

Figure 4. Similar to Fig. 3, but for the FDR-averaged differences of MET_AOD minus MET for (a) AOD, (b) vertical velocity, (c) temperature (contours) and relative humidity (color shaded) and (d) liquid and ice clouds as a function of height and time.

precipitation decreased by up to $0.03 \mathrm{~mm} \mathrm{grid}^{-1}(7.3 \%)$ late on 16 August, and the average precipitation during the fire week was reduced by $2.0 \%$, perhaps associated with the suppressed middle clouds and ice clouds (Fig. 4d) (Rosenfeld et al., 2008). The radiative impact of aerosols on precipitation reported here is consistent with Zhao et al. (2011) and Wu et al. (2011), who focused on Asian dust and Amazon fires, respectively. Overall, WRF/Chem produced reasonably good precipitation forecasts when compared to Stage IV observations even though the total amount was usually overpredicted.

\section{Summary}

The GSI 3DVAR DA system coupled with the WRF/Chem model successfully simulated surface $\mathrm{BC}, \mathrm{OC}$, and $\mathrm{PM}_{2.5}$ during a wild fire event without any fire emission input in the model. By assimilating total $550 \mathrm{~nm}$ AOD retrievals from MODIS sensors, surface $\mathrm{PM}_{2.5}$ and $\mathrm{OC}$ in the fire originating regions were substantially improved compared to those when AOD was not assimilated. The increased aerosols in the downwind regions were dominated by $\mathrm{OC}$ and other oxidized $\mathrm{PM}_{2.5}$ components, which are mainly scattering aerosols.

Direct and semi-direct aerosol radiative effects due to aerosols in the downwind region were investigated. Enhanced scattering aerosol concentrations due to AOD DA cooled layers both below and above the aerosol layer, leading to changes in the temperature, relative humidity, vertical velocity and clouds. We found that the radiative effect of the increased AOD (varied from $\sim 0.2-\sim 0.4$ ) was to increase cloud amount in the PBL and suppress middle-level liquid clouds and high-level ice clouds. A $2 \%$ average reduction of total precipitation due to aerosol increase was also evident. This study demonstrated the value of aerosol DA for more accurately depicting the aerosol spatial distribution and speciation and thus allowed a more realistic model simulation of aerosol radiative effects during a fire event even with no input of fire emissions.

Grell et al. (2011) showed that the inclusion of fire emissions and a plume rise scheme resulted in strong modifications of cloud and precipitation features in high-resolution $(10 \mathrm{~km} / 2 \mathrm{~km}$ nested domains) WRF/Chem simulations with both direct and indirect aerosol feedbacks for a wildfire event over Alaska. However, in our initial trials, the inclusion of GOES WF_ABBA (Geostationary Operational Environmental Satellite - Wildfire Automated Biomass Burning Algorithm) (Prins et al., 1998) fire emissions in the simulation of this fire event over California led to a substantial overestimation of aerosol concentrations when compared to surface $\mathrm{PM}_{2.5}$, OC and $\mathrm{BC}$ measurements (not shown). The impact of AOD DA together with the inclusion of fire emissions will be further investigated in the future.

Acknowledgements. This work is supported by grants from the US Air Force Weather Agency. NCAR is sponsored by the National Science Foundation.

Edited by: G. Folberth 


\section{References}

Andreae, M. O., Rosenfeld, D., Artaxo, P., Costa, A. A., Frank, G. P., Longo, K. M., and Silva-Dias, M. A. F.: Smoking rain clouds over the Amazon, Science, 303, 1337-1342, doi:10.1126/science.1092779, 2004.

Barnard, J. C., Fast, J. D., Paredes-Miranda, G., Arnott, W. P., and Laskin, A.: Technical Note: Evaluation of the WRF-Chem "Aerosol Chemical to Aerosol Optical Properties" Module using data from the MILAGRO campaign, Atmos. Chem. Phys., 10, 7325-7340, doi:10.5194/acp-10-7325-2010, 2010.

Charlson, R. J., Schwartz, S. E., Hales, J. M., Cess, R. D., Coakley, J. A., Hansen, J. E., and Hofmann, D. J.: Climate Forcing by Anthropogenic Aerosols, Science, 255, 423-430, doi:10.1126/science.255.5043.423, 1992.

Chin, M., Savoie, D. L., Huebert, B. J., Bandy, A. R., Thornton, D. C., Bates, T. S., Quinn, P. K., Saltzman, E. S., and De Bruyn, W. J.: Atmospheric sulfur cycle simulated in the global model GOCART: Comparison with field observations and regional budgets, J. Geophys. Res.-Atmos., 105, 24689-24712, doi:10.1029/2000jd900385, 2000.

Chin, M., Ginoux, P., Kinne, S., Torres, O., Holben, B. N., Duncan, B. N., Martin, R. V., Logan, J. A., Higurashi, A., and Nakajima, T.: Tropospheric aerosol optical thickness from the GOCART model and comparisons with satellite and Sun photometer measurements, J. Atmos. Sci., 59, 461-483, doi:10.1175/15200469(2002)059<0461:Taotft>2.0.Co;2, 2002.

Chou, M.-D. and Suarez, M. J.: An efficient thermal infrared radiation parameterization for use in general circulation models, NASA Tech. Memo., TM 104606, Vol. 3, 25 pp., NASA Goddard Space Flight Cent., Greenbelt, Md, 1994.

Collins, W. D., Rasch, P. J., Eaton, B. E., Khattatov, B. V., Lamarque, J. F., and Zender, C. S.: Simulating aerosols using a chemical transport model with assimilation of satellite aerosol retrievals: Methodology for INDOEX, J. Geophys. Res.-Atmos., 106, 7313-7336, doi:10.1029/2000jd900507, 2001.

Fast, J. D., Gustafson, W. I., Easter, R. C., Zaveri, R. A., Barnard, J. C., Chapman, E. G., Grell, G. A., and Peckham, S. E.: Evolution of ozone, particulates, and aerosol direct radiative forcing in the vicinity of Houston using a fully coupled meteorologychemistry-aerosol model, J. Geophys Res.-Atmos., 111, D21305, doi:10.1029/2005jd006721, 2006.

Grell, G. A. and Devenyi, D.: A generalized approach to parameterizing convection combining ensemble and data assimilation techniques, Geophys. Res. Lett., 29, 1693, doi:10.1029/2002g1015311, 2002.

Grell, G. A., Peckham, S. E., Schmitz, R., McKeen, S. A., Frost, G., Skamarock, W. C., and Eder, B.: Fully coupled "online" chemistry within the WRF model, Atmos. Environ., 39, 6957-6975, doi:10.1016/j.atmosenv.2005.04.027, 2005.

Grell, G., Freitas, S. R., Stuefer, M., and Fast, J.: Inclusion of biomass burning in WRF-Chem: impact of wildfires on weather forecasts, Atmos. Chem. Phys., 11, 5289-5303, doi:10.5194/acp11-5289-2011, 2011.

Hansen, J., Sato, M., and Ruedy, R.: Radiative forcing and climate response, J. Geophys. Res.-Atmos., 102, 6831-6864, doi:10.1029/96jd03436, 1997.
Jacobson, M. Z.: Control of fossil-fuel particulate black carbon and organic matter, possibly the most effective method of slowing global warming, J. Geophys. Res., 107, 4410, doi:10.1029/2001JD001376, 2002.

Jiang, Z. Q., Liu, Z. Q., Wang, T. J., Schwartz, C. S., Lin, H. C., and Jiang, F.: Probing into the impact of 3DVAR assimilation of surface $\mathrm{PM}_{10}$ observations over China using process analysis, J. Geophys. Res.-Atmos., 118, 6738-6749, doi:10.1002/Jgrd.50495, 2013.

Kahnert, M.: On the observability of chemical and physical aerosol properties by optical observations: Inverse modeling with variational data assimilation, Tellus B, 61, 747-755, 2009.

Kaufman, Y. J. and Koren, I.: Smoke and pollution aerosol effect on cloud cover, Science, 313, 655-658, doi:10.1126/science.1126232, 2006.

Kiehl, J. T. and Briegleb, B. P.: The Relative Roles of Sulfate Aerosols and Greenhouse Gases in Climate Forcing, Science, 260, 311-314, doi:10.1126/science.260.5106.311, 1993.

Kim, S.-W., McKeen, S. A., Frost, G. J., Lee, S.-H., Trainer, M., Richter, A., Angevine, W. M., Atlas, E., Bianco, L., Boersma, K. F., Brioude, J., Burrows, J. P., de Gouw, J., Fried, A., Gleason, J., Hilboll, A., Mellqvist, J., Peischl, J., Richter, D., Rivera, C., Ryerson, T., te Lintel Hekkert, S., Walega, J., Warneke, C., Weibring, P., and Williams, E.: Evaluations of $\mathrm{NO}_{\mathrm{x}}$ and highly reactive VOC emission inventories in Texas and their implications for ozone plume simulations during the Texas Air Quality Study 2006, Atmos. Chem. Phys., 11, 11361-11386, doi:10.5194/acp11-11361-2011, 2011.

Koren, I., Kaufman, Y. J., Remer, L. A., and Martins, J. V.: Measurement of the effect of Amazon smoke on inhibition of cloud formation, Science, 303, 1342-1345, doi:10.1126/science.1089424, 2004.

Koren, I., Martins, J. V., Remer, L. A., and Afargan, H.: Smoke invigoration versus inhibition of clouds over the Amazon, Science, 321, 946-949, doi:10.1126/science.1159185, 2008.

Liu, Z. Q., Liu, Q. H., Lin, H. C., Schwartz, C. S., Lee, Y. H., and Wang, T. J.: Three-dimensional variational assimilation of MODIS aerosol optical depth: Implementation and application to a dust storm over East Asia, J. Geophys. Res.-Atmos., 116, D23206, doi:10.1029/2011jd016159, 2011.

Prins, E. M., Feltz, J. M., Menzel, W. P., and Ward, D. E.: An overview of GOES- 8 diurnal fire and smoke results for SCAR-B and 1995 fire season in South America, J. Geophys. Res.-Atmos., 103, 31821-31835, doi:10.1029/98jd01720, 1998.

Rosenfeld, D., Lohmann, U., Raga, G. B., O’Dowd, C. D., Kulmala, M., Fuzzi, S., Reissell, A., and Andreae, M. O.: Flood or drought: How do aerosols affect precipitation?, Science, 321, 1309-1313, doi:10.1126/science.1160606, 2008.

Schwartz, C. S., Liu, Z. Q., Lin, H. C., and McKeen, S. A.: Simultaneous three-dimensional variational assimilation of surface fine particulate matter and MODIS aerosol optical depth, J. Geophys. Res.-Atmos., 117, D13202, doi:10.1029/2011jd017383, 2012.

Wilcox, E. M.: Direct and semi-direct radiative forcing of smoke aerosols over clouds, Atmos. Chem. Phys., 12, 139-149, doi:10.5194/acp-12-139-2012, 2012. 
Wu, W. S., Purser, R. J., and Parrish, D. F.: Three-dimensional variational analysis with spatially inhomogeneous covariances, Mon. Weather Rev., 130, 2905-2916, doi:10.1175/15200493(2002)130<2905:Tdvaws>2.0.Co;2, 2002.

Wu, L. T., Su, H., and Jiang, J. H.: Regional simulations of deep convection and biomass burning over South America: 2. Biomass burning aerosol effects on clouds and precipitation, J. Geophys. Res.-Atmos., 116, D17209, doi:10.1029/2011jd016106, 2011.
Zhao, C., Liu, X., Ruby Leung, L., and Hagos, S.: Radiative impact of mineral dust on monsoon precipitation variability over West Africa, Atmos. Chem. Phys., 11, 1879-1893, doi:10.5194/acp11-1879-2011, 2011. 